\title{
UPAYA PENGEMBANGAN USAHA BUDIDAYA UDANG VANNAME (Litopenaeus vannamei) DI DESA SIDOKUMPUL KECAMATAN LAMONGAN KABUPATEN LAMONGAN
}

\section{*Ika Purnamasari, Moch Saad, Mukti Ali, Muntalim, Mohammad Hafid Ardiansya}

*Fakultas Perikanan Universitas Islam Lamongan

Jl. Veteran no. 53A Lamongan Phone/Fax. 0322_324706

\begin{abstract}
ABSTRAK
Udang vannamei merupakan salah satu komoditas utama dalam usaha budidaya tambak, namun masih banyak berbagai permasalahan yang dihadapi petambak dalam usaha pengembangan budidaya udang vannamei. Tujuan dari penelitian ini adalah untuk menegetahui upaya dan prioritas strategi yang dapat diterapkan dalam mengembangkan usaha udang vannamei di Desa Sidokumpul, Kecamatan Lamongan, Kabupaten Lamongan. Hasil penelitian menunjukkan bahwa peluang utama dalam mengembangkan usaha udang vanname adalah lingkungan yang aman dan terkendali. Sedangkan ancaman yang paling besar yaitu harga udang vanname dari daerah lain yang lebih murah. Prioritas strategi yang dapat diterapkan dalam upaya mengembangkan usaha budidaya udang vanname di Kabupaten Lamongan yaitu mempertahankan kualitas, promosi perikanan, jaringan distribusi udang vanname, kemitraan, dan penanaman modal swasta untuk menembus pasar ekspor; optimalisasi pemberdayaan, peningkatan jumlah unit-unit pembenihan (Unit pembenihan Rakyat) dan perbaikan sarana dan prasarana lokasi budidaya serta meningkatkan kualitas sumber daya petani secara teknis, moral dan spiritual melalui kegiatan pembinaan untuk memaksimalkan produksi dan daya saing udang vanname.
\end{abstract}

Kata kunci : Budidaya, Udang Vannemai, Upaya Pengembangan

\section{PENDAHULUAN}

Udang vanamei (Litopenaeus vannamei) atau dikenal dengan Pacific White Shrimp merupakan udang introduksi yang secara ekonomis bernilai tinggi karena diminati oleh pasar Amerika dan dunia. (Sugama, 2002).

Beberapa keunggulan udang vannamei tahan terhadap penyakit dan tingkat produktivitas yang tinggi. Kebutuhan udang vannamei akan kandungan protein pakan yang relatif rendah, dan tumbuh cepat, toleran terhadap suhu air, oksigen terlarut dan salinitas yang relatif rendah (Sudrajad, 2011).
Permasalahan utama yang sering ditemukan dalam kegagalan produksi udang vaname adalah buruknya kualitas air selama masa pemeliharaan, terutama pada tambak intensif. Padat tebar yang tinggi dan pemberian pakan yang banyak dapat menurunkan kondisi kualitas air (Yuniasari, 2009).

Terlepas dari berbagai permasalahan, namun hingga saat ini komoditas udang vannamei masih merupakan pilihan utama untuk dibudidayakan oleh petambak. Hal ini dikarenakan secara ekonomi keberhasilan panen udang vannamei ukuran konsumsi memberikan keuntungan yang tertinggi per satuan waktu dibandingkan dengan komoditas 
ikan lainya selain itu udang vannamei mempunyai harga pasar yang baik dan relatif stabil.

Tujuan dari penelitian ini adalah untuk mengetahui upaya dan prioritas strategi yang dapat diterapkan dalam mengembangkan usaha budidaya udang vannamei.

\section{METODE PENELITIAN}

\section{Tempat dan Waktu}

Penelitian ini dilakukan di Desa Sidokumpul, Kecamatan Lamongan, Kabupaten Lamongan pada bulam April hingga Juni 2017.

\section{Metode Penentuan Sampel}

Penentuan sampel yang digunakan dalam penelitian ini yaitu teknik non probabbility sampling dengan metode purposive. Jumlah responden yang diambil adalah 10 orang. Pemilihan responden dipilih secara sengaja dan bersedia diwawancarai sebagai langkah dalam mengumpulkan data dari para responden.

\section{Metode Penelitian dan Analisis Data} Metode penelitian yang digunakan yaitu metode deskriptif kualitatif digunakan untuk mengidentifikasi gambaran umum kondisi para pembudidaya udang vaname dan mengidentifikasi kekuatan serta kelemahan dari faktor internal serta peluang dan ancaman dari faktor eksternal dalam upaya mengembangkan usaha budidaya udang vanname di lokasi penelitian.

$$
\text { Untuk mengidentifikasi }
$$

kekuatan dan kelemahan dari faktor internal serta peluang dan ancaman dari faktor eksternal dalam upaya mengembangkan usaha budidaya udang vanname di Kabupaten Lamongan digunakan analisis SWOT. Rangkuti (2001), menjelaskan Analisis SWOT adalah identifikasi berbagai faktor secara sistematis untuk merumuskan strategi perusahaan. Analisis ini didasarkan pada logika yang dapat memaksimalkan kekuatan (strengths) dan peluang (opportunities), namun secara bersamaan dapat meminimalkan kelemahan (weaknesses) dan ancaman (threats).

\section{HASIL DAN PEMBAHASAN \\ Analisis Faktor Internal dan Eksternal}

Faktor internal dan eksternal usaha budidaya udang vanamei dapat dilihat pada Tabel 1.

Tabel 1. Matriks IFE

\begin{tabular}{|c|c|c|c|c|}
\hline No. & Faktor Strategis Internal & Bobot & Rating & Skor \\
\hline & KEKUATAN & & & \\
\hline 1 & $\begin{array}{l}\text { Lokasi dekat dengan } \\
\text { bahan baku dan } \\
\text { transportasi mudah }\end{array}$ & 0,074 & 3,500 & 0,259 \\
\hline 2. & $\begin{array}{l}\text { Produk yang dihasilkan } \\
\text { berkualitas }\end{array}$ & 0,082 & 3,500 & 0,287 \\
\hline 3. & $\begin{array}{l}\text { Hubungan dan pelayanan } \\
\text { yang baik kepada } \\
\text { pelanggan }\end{array}$ & 0,079 & 3,500 & 0,277 \\
\hline 4. & $\begin{array}{ll}\text { Daerah yang dapat } \\
\text { digunakan } \\
\text { pembenihan }\end{array}$ & 0,082 & 4,000 & 0,382 \\
\hline 5. & $\begin{array}{l}\text { Jaringan pemasaran yang } \\
\text { sudah kuat }\end{array}$ & 0,079 & 3,500 & 0,277 \\
\hline 6. & $\begin{array}{l}\text { Komunikasi yang baik } \\
\text { antara pemilik dan } \\
\text { karyawan }\end{array}$ & 0,093 & 3,000 & 0,279 \\
\hline 7. & Keuntungan tinggi & 0,090 & 2,000 & 0,315 \\
\hline & KELEMAHAN & & & \\
\hline 1. & $\begin{array}{l}\text { Pasar yang dituju sama } \\
\text { dengan desa lain }\end{array}$ & 0,063 & 2,000 & 0,126 \\
\hline 2. & $\begin{array}{l}\text { Pakan alami masih } \\
\text { tergantung musim }\end{array}$ & 0,063 & 1,500 & 0,095 \\
\hline 3. & $\begin{array}{l}\text { Jumlah produksi benih } \\
\text { udang vanname } \\
\text { berfluktuasi }\end{array}$ & 0,067 & 1,500 & 0,101 \\
\hline 4. & $\begin{array}{l}\text { Kerugian kematian benih } \\
\text { saat pengiriman menjadi } \\
\text { tanggungjawab } \\
\text { pembudidaya }\end{array}$ & 0,063 & 2,000 & 0,126 \\
\hline 5. & $\begin{array}{l}\text { Tidak adanya asuransi } \\
\text { dari pemerintah }\end{array}$ & 0,085 & 1,500 & 0,128 \\
\hline & TOTAL & 1,000 & & 2,648 \\
\hline
\end{tabular}


Tabel 2. Matriks EFE

\begin{tabular}{clccc}
\hline No. & Faktor Strategis Eksternal & Bobot & Rating & Skor \\
\hline & PELUANG & & & \\
1 & Peningkatan jumlah petambak udang vanname & 0,080 & 3,000 & 0,240 \\
2. & $\begin{array}{l}\text { Adanya kebijakan pemerintah yang mendorong peningkatan } \\
\text { ekspor udang vanname }\end{array}$ & 0,084 & 3,000 & 0,252 \\
3. & & & \\
4. & Terosotnya produksi udang windu & 0,150 & 3,500 & 0,368 \\
5. & Harga relative rendah dibanding dengan udang windu & 0,082 & 3,500 & 0,287 \\
\hline ANCAMAN & 0,084 & 3,000 & 0,252 \\
\hline 1. & Persaingan antara komoditas sejenis & & & \\
2. & Adanya kenaikan biaya pembenihan & 0,093 & 3,000 & 0,279 \\
3. & Keadaan iklim yang mempengaruhi ketersediaan bahan baku & 0,089 & 3,000 & 0,267 \\
4. & Ancaman produk substitusi & 0,095 & 3,000 & 0,285 \\
5. & Adanya penyakit dan bakteri & 0,098 & 3,500 & 0,223 \\
& TOTAL & 1,000 & & 3,343 \\
\hline
\end{tabular}

\section{Identifikasi Faktor Kekuatan, Kelemahan, Peluang dan Ancaman}

Berdasarkan hasil analisis faktor internal dan eksternal maka dapat diidentifikasi kekuatan, kelemahan, peluang dan ancaman yang berpengaruh terhadap pengembangan usahatani Udang vanname di Desa Sidokumpul Kecamatan Lamongan Kabupaten Lamongan. Adapun faktor-faktor tersebut dapat dilihat pada Tabel 3.

Tabel 3. Identifikasi Kekuatan, Kelemahan, Peluang dan Ancaman dalam Pengembangan Usahatani Udang vanname di Kabupaten Lamongan

\begin{tabular}{|c|c|c|}
\hline Faktor Internal & Kekuatan & Kelemahan \\
\hline Sumberdaya Manusia & & Kemampuan petani terbatas \\
\hline Pemasaran & $\begin{array}{ll}\checkmark & \text { Kualitas udang vanname } \\
\checkmark & \text { Kontinuitas hasil panen udang } \\
\text { vanname }\end{array}$ & Kondisi transportasi yang buruk \\
\hline $\begin{array}{l}\text { Produk / operasional } \\
\text { Manajemen }\end{array}$ & $\begin{array}{ll}\checkmark & \text { Budidaya mudah dan resiko kecil } \\
\checkmark & \text { Potensi sumberdaya yang dimiliki } \\
\checkmark & \text { Saprodi mudah didapat }\end{array}$ & $\begin{array}{l}\text { Pengelolaan kurang optimal } \\
\checkmark \quad \text { Belum bisa mengusahakan } \\
\text { pembenihan dan pendederan } \\
\text { udang vanname sendiri } \\
\checkmark \text { Pengelolaan keuangan petani yang } \\
\text { kurang baik. } \\
\end{array}$ \\
\hline Faktor eksternal & Peluang & Ancaman \\
\hline Kondisi perekonomian & & $\begin{array}{l}\text { Kenaikan harga sembako dan pakan } \\
\text { ternak }\end{array}$ \\
\hline Sosial dan budaya & $\begin{array}{l}\checkmark \text { Permintaan produk udang yang } \\
\text { semakin meningkat } \\
\checkmark \text { Hubungan yang dekat dengan } \\
\text { stakeholder } \\
\checkmark \text { Kondisi lingkungan yang aman } \\
\text { dan terkendali }\end{array}$ & $\begin{array}{ll}\checkmark & \text { Kesenjangan sosial } \\
\checkmark & \text { Pembuangan limbah yang } \\
& \text { menganggu masyarakat }\end{array}$ \\
\hline Politik dan hukum & $\begin{array}{l}\text { Perhatian pemerintah terhadap } \\
\text { pengembangan budidaya udang }\end{array}$ & \\
\hline Teknologi & $\begin{array}{l}\text { Perkembangan teknologi pengelolaan } \\
\text { pangan }\end{array}$ & \\
\hline Persaingan & & $\begin{array}{l}\checkmark \text { Harga udang vanname dari daerah } \\
\text { lain yang lebih rendah } \\
\checkmark \text { Peningkatan pemasaran ikan laut }\end{array}$ \\
\hline
\end{tabular}




\section{Alternatif Strategi}

Dalam merumuskan alternatif strategi dalam upaya mengembangkan usaha budidaya udang vanname di Kabupaten Lamongan digunakan analisis Matriks SWOT seperti pada Tabel 4.

Tabel 4. Alternatif Matrix SWOT Upaya Pengembangan Udang vannamei

\begin{tabular}{|c|c|c|}
\hline & Kekuatan -S & Kelemahan -W \\
\hline & $\begin{array}{ll}\text { 1. } & \text { Kualitas udang vanname } \\
\text { 2. } & \text { Budidaya mudah dan } \\
\text { resiko kecil } \\
\text { 3. Saprodi mudah didapat } \\
\text { 4. Kontinuitas hasil panen } \\
\text { udang vanname } \\
\text { 5. Potensi SDA yang dimiliki }\end{array}$ & $\begin{array}{l}\text { 1. Kemampuan petani terbatas } \\
\text { 2. Belum bisa mengusahakan } \\
\text { pembenihan dan pendederan } \\
\text { udang vanname sendiri }\end{array}$ \\
\hline Peluang $-\mathrm{O}$ & Strategi $-\mathrm{SO}$ & Strategi W-O \\
\hline $\begin{array}{l}\text { 1. Kondisi lingkungan yang } \\
\text { aman dan terkendali } \\
\text { 2. Memiliki hubungan yang } \\
\text { dekat dengan distributor } \\
\text { 3. Perkembangan teknologi } \\
\text { pengolahan pangan } \\
\text { 4. Permintaan terhadap } \\
\text { produk semakin } \\
\text { meningkat } \\
\text { 5. Perhatian pemerintah } \\
\text { terhadap perkembangan } \\
\text { budidaya udang vanname }\end{array}$ & $\begin{array}{l}\text { 1. Mempertahankan kualitas, } \\
\text { promosi perikanan, } \\
\text { jaringan distribusi udang } \\
\text { vanname, kemitraan dan } \\
\text { penanaman modal swasta, } \\
\text { untuk menembus pasar } \\
\text { ekspor. } \\
\text { 2. Peningkatan lahan } \\
\text { budidaya dan pemanfaatan } \\
\text { sumberdaya yang ada } \\
\text { dengan dukungan } \\
\text { pemerintah }\end{array}$ & $\begin{array}{l}\text { 1. Optimalisasi pemberdayaan } \\
\text { peningkatan jumlah unit-unit } \\
\text { pembenihan dan perbaikan } \\
\text { sarana prasarana budidaya } \\
\text { 2. Peningkatan pemasaran hasil } \\
\text { produk olahan udang vanname } \\
\text { melalui promosi produk } \\
\text { unggulan disertai dengan } \\
\text { koordinasi antara instansi yang } \\
\text { terkait dalam rangka } \\
\text { permodalan a dan } \\
\text { pengembangan pasar produk } \\
\text { olahan udang vanname }\end{array}$ \\
\hline
\end{tabular}

Ancaman -T

1. Harga udang vanname dari daerah lain lebih murah

2. Peningkatan pemasaran ikan laut

3. Kenaikan harga sembako dan pakan ternak

4. Kesenjangan sosial

5. Limbah pembuangan udang vanname yang menganggu masyarakat

\section{Strategi $-\mathrm{ST}$}

1. Mempertahankan dan meningkatkan kualitas produk pembesaran udang vanname dan mengefisienkan penggunaan sarana produksi

2. Pengelolaan sumberdaya alam dan limbah secara maksimaloleh pemerintah dan masyarakat

\section{Strategi W-T}

1. Meningkatkan kualitas sumberdaya petani secara teknis, moral dan spiritual melalui kegiatan pembinaan untuk memaksimalkan produksi dan daya saing udang vanname

2. Menjalin kerja sama dengan masyarakat sekitar dalam rangka menjaga keharmonisan dan menambah kesempatan kerja

\section{Prioritas Strategi}

Hasil analisis prioritas strategi dalam upaya mengembangkan usaha budidaya udang vanname di Kabupaten Lamongan sebagai berikut :

a. Mempertahankan kualitas, promosi perikanan, jaringan distribusi udang vanname, kemitraan, dan penanaman modal swasta untuk menembus pasar ekspor

b. Optimalisasi pemberdayaan, peningkatan jumlah unit-unit pembenihan (Unit Pembenihan Rakyat) dan perbaikan sarana dan prasarana lokasi budidaya.

c. Meningkatkan kualitas sumber daya petani secara teknis, moral 
dan spiritual melalui kegiatan pembinaan untuk memaksimalkan produksi dan daya saing udang vanname.

\section{KESIMPULAN DAN SARAN Kesimpulan}

Berdasarkan hasil penelitian mengenai Upaya Pengembangan Usaha budidaya udang vanname di Desa Sidokumpul Kecamatan Lamongan Kabupaten Lamongan, dapat ditarik kesimpulan sebagai berikut :

1. Kekuatan utama dalam mengembangkan usaha budidaya udang vanname yaitu kualitas udang vanname yang bagus dan sudah diakui masyarakat dan kelemahannya yaitu ketrampilan petani rendah. Sedangkan Peluang utama adalah lingkungan yang aman dan terkendali, dan ancaman yang paling besar yaitu harga udang vanname dari daerah lain yang lebih murah.

2. Prioritas strategi yang dapat diterapkan dalam uapaya mengembangkan usaha budidaya udang vanname di Kabupaten Lamongan yaitu mempertahankan kualitas, promosi perikanan, jaringan distribusi udang vanname, kemitraan, dan penanaman modal swasta untuk menembus pasar ekspor; optimalisasi pemberdayaan, peningkatan jumlah unit-unit pembenihan dan perbaikan sarana dan prasarana lokasi budidaya serta meningkatkan kualitas sumber daya petani secara teknis, moral dan spiritual melalui kegiatan pembinaan untuk memaksimalkan produksi dan daya saing udang vanname.

\section{Saran}

Petani udang vanname sebaiknya meningkatkan keterampilan dalam mengusahakan udang vanname baik secara teknis maupun operasional melalui berbagai media contohnya melalui buku, majalah, dan sumber informasi lainnya.

Pemerintah diharapkan lebih berperan dalam melakukan pembinaan kepada petani untuk meningkatkan semangat petani dalam mengusahakan budidaya udang vanname, baik melalui kegiatan-kegiatan penyuluhan maupun pelatihan teknis budidaya terpadu dan pembinaan social

\section{DAFTAR PUSTAKA}

Avnimelech, Y. 2009. Biofloc Technology, a Practical Guide Book. World Aquaculture Society. Bato Rounge, Lousiana, Amaerika Serikat.

\section{Rangkuti, F. 2001. Analisis SWOT Teknik Membedah Kasus Bisnis. Gramedia Pustaka Utama. Jakarta.}

Sudrajat A, Wedjatmiko. 2010. Budidaya Udang di Sawah dan Tambak. [internet]. [diunduh 22 Agustus 2014]]. Tersedia pada : http://books.google.co.id/.

Sugama, K. 2002. Status budidaya udang introduksi Litopenaeus vannamei dan Litopenaeus Stylirostris serta prospek pengembangannya dalam tambak air tawar. Disampaikan dalam Temu Bisnis Udang. Makassar, 19 Oktober 2002. 